\title{
Intracellular Pancreatic B Cell Serotonin and the Dynamics of Insulin Release
}

\author{
O. M. Pulido, S. A. Bencosme, M. L. de Bold, and A. J. de Bold \\ Department of Pathology, Queen's University, Kingston General and Hotel Dieu Hospitals, Kingston, Ontario, Canada
}

\begin{abstract}
Summary. The role of intracellular pancreatic B cell serotonin in the dynamics of insulin release was investigated in an in situ perfused rat pancreas preparation. Animals were pretreated with 5-hydroxytryptophan (5-HTP) to increase the intracellular levels of serotonin (5-HT) as shown by fluorescence histochemistry. Despite a clear induction of intracellular 5-HT fluorescence in pancreatic islets neither the pattern nor the total amount of insulin released were significantly modified after perfusion with either glucose or tolbutamide. However, the L-amino acid decarboxylase inhibitor, RO 4-4602, significantly decreased both phases of glucose-mediated insulin release in normal animals as well as in those receiving 5-HTP.
\end{abstract}

Key words: Insulin, pancreatic B cells, serotonin, fluorescence microscopy, monoamine oxidase, Laromatic amino acid decarboxylase.

Evidence accumulated over the past few years has led to the hypothesis that intracellular B cell serotonin (5-HT) acts as a tonic inhibitor of insulin release. Serotonin is reported to inhibit glucose-mediated insulin release in vitro after administration of the precursor 5-hydroxytryptophan (5-HTP) $[18,26,36$, 37]. Additionally, drugs reported to be specific serotonin antagonists have been shown to potentiate the glucose- and tolbutamide-induced insulin release in adult onset diabetic patients $[1,2,33]$, acromegalic patients with glucose intolerance $[4,20]$ and normal subjects [30]. Similar results have been obtained in vitro using pieces of rabbit pancreas $[18,19]$ and in the in situ perfused rat pancreas [11]. The precise mechanism of potentiation of glucose-induced insulin release caused by these serotonin antagonists has not been established and may be unrelated to their antiserotoninergic action $[13,17,35]$. In addition to this uncertainty, a conflict arises from other in vivo studies in which no inhibition of glucose-mediated insulin release was observed in either mice [28] or humans [34] pretreated with 5-HTP.

We have previously found $[9,10,13]$ that serotonin, incorporated into the perfusion fluid of the in situ perfused pancreas preparation at a concentration of $1.0 \times 10^{-5} \mathrm{M}$ significantly inhibited the glucosemediated first phase of insulin release but did not affect the basal release of insulin. In the present study we have evaluated the role of intracellular B cell serotonin in the dynamics of insulin release using the same in situ perfused pancreas preparation. Rat pancreases containing high levels of experimentally induced intracellular B cell serotonin, as indicated by fluorescence histochemistry [31], were perfused with glucose or tolbutamide.

\section{Materials and Methods}

\section{Chemicals}

L-5-hydroxytyptophan (5-HTP) and the monoaminoxidase (MAO) inhibitor, nialamide, were obtained from the Sigma Chemical Company (St. Louis, Missouri, U.S.A.); Tolbutamide (Orinase $^{\mathrm{R}}$ ) from Upjohn (Kalamazoo, Michigan, U.S.A.); Sodium Amytal $^{\mathrm{R}}$ from Eli Lilly Company (Toronto, Ontario, Canada); Kits for insulin radioimmunoassay (Phadebas ${ }^{R}$ ) from Pharmacia (Montreal, Quebec, Canada). The L-aromatic amino acid decarboxylase inhibitor, RO 4-4602, was a gift from Hoffman-LaRoche Limited (Vaudreuil, Quebec, Canada).

Induction of 5-HT Fluorescence in Pancreatic Islets

Serotonin within islet cells was visualized using the formaldehyde condensation technique [5]. Pancreatic biopsies were frozen in 
Table 1. Summary of experimental protocol used to assess the effect of elevated intracellular B cell serotonin on dynamics of glucose- and tolbutamide-mediated insulin release. In the glucose stimulation experiments the pancreases from four animals in each group were biopsied before and after surgery; in groups $\mathrm{B}$ and $\mathrm{E}$ the pancreases from three animals were perfused with $4.4 \mathrm{mmol} / \mathrm{l}$ glucose; in all groups the pancreases from the remaining animals were perfused with $16.6 \mathrm{mmol} / 1$ glucose. In all instances a pancreatic biopsy was taken at the end of perfusion

\begin{tabular}{|c|c|c|c|c|}
\hline Stimulus & Group (n) ${ }^{\mathrm{b}}$ & Treatment & & \\
\hline \multirow{11}{*}{ Glucose } & $A(16)$ & No treatment & & \\
\hline & B (19) & Saline & $\&$ & Saline $^{\mathrm{a}}$ \\
\hline & $C(10)$ & Nialamide & $\&$ & Saline ${ }^{a}$ \\
\hline & $\mathrm{D}(10)$ & Saline & $\&$ & 5-HTP \\
\hline & $\mathrm{E}(13)$ & Nialamide & $\&$ & 5-HTP \\
\hline & $F(10)$ & RO 4-4602 & & \\
\hline & & $\begin{array}{l}\text { immediately } \\
\text { prior to }\end{array}$ & & \\
\hline & & Nialamide & $\&$ & 5-HTP \\
\hline & $\mathrm{G}(10)$ & $\mathrm{RO} 4-4602$ & & \\
\hline & & $\begin{array}{l}\text { immediately } \\
\text { prior to }\end{array}$ & & \\
\hline & & Saline & $\&$ & Saline $^{\mathrm{a}}$ \\
\hline \multirow[t]{2}{*}{ Tolbutamide } & $H(5)$ & Saline & $\&$ & Saline $^{\mathrm{a}}$ \\
\hline & $I(5)$ & Nialamide & $\&$ & 5-HTPa \\
\hline
\end{tabular}

a Given after an interval of $1 \mathrm{~h}$

$b$ (n) number of animals used in each group

isopentane/liquid nitrogen and freeze-dried under vacuum for $24 \mathrm{~h}$ in an Edward-Pearse tissue dryer. The tissue was then treated with paraformaldehyde vapour at $80^{\circ} \mathrm{C}$ for $1 \mathrm{~h}$ and embedded in paraffin. Slides were examined under a fluorescence microscope equipped with a combination of KP 500/K 510 filters. The intensity of the fluorescence observed within islet cells was evaluated and graded as slight, moderate, or intense.

In a previous communication [31] we have described conditions to induce accumulation of serotonin in rat pancreatic islet cells. Briefly, injection of nialamide $(5 \mathrm{mg} / \mathrm{kg}$ body weight) followed by 5 -HTP $(50 \mathrm{mg} / \mathrm{kg}$ body weight $)$ one hour later, resulted in intense serotonin fluorescence observed at $120 \mathrm{~min}$ after injection of 5-HTP. Injection of 5-HTP alone produced similar but weaker results in terms of serotonin fluorescence.

In the present investigations we carried out pilot experiments to determine changes in serotonin fluorescence at different time intervals after 5-HTP injection. To this purpose, two groups of 12 animals each were injected intraperitoneally with either nialamide $(5 \mathrm{mg} / \mathrm{kg}$ body weight) and, $60 \mathrm{~min}$ later, with $5-\mathrm{HTP}(50 \mathrm{mg} / \mathrm{kg}$ body weight) or with 5 -HTP alone $(50 \mathrm{mg} / \mathrm{kg}$ body weight). At 15 , 30,60 and 120 min after 5-HTP injection, 3 animals from each group were anaesthetized with $\mathrm{Na} \mathrm{Amytal}^{\mathrm{R}}$ and pieces of pancreas were taken for histochemical evaluation. Serotonin fluorescence was evident in pancreatic islets from both groups as early as $15 \mathrm{~min}$ after 5-HTP injection, increasing through $60 \mathrm{~min}$ and remaining unaltered for up to $120 \mathrm{~min}$. The fluorescence displayed by islet cells in animals treated with 5-HTP alone was consistently lower than that observed in animals treated with both nialamide and 5-HTP. As no change in fluorescence was apparent after $60 \mathrm{~min}$ of 5-HTP administration, this time period was chosen to perform the investigations described below.

\section{Perfusion Technique}

Male Sprague-Dawley rats weighing $275-325 \mathrm{~g}$ were fasted for $18-20 \mathrm{~h}$, anaesthetized with sodium Amytal $^{\mathrm{R}}(100 \mathrm{mg} / \mathrm{kg}$ body weight) and the pancreas isolated in situ [29]. The basic buffer used for perfusion of the gland was supplemented Krebs-Ringer bicarbonate [2], pH: 7.4, containing glucose $4.4 \mathrm{mmol} / \mathrm{l}$ and Dex$\operatorname{tran} \mathrm{T} 40,60 \mathrm{mg} / \mathrm{ml}$ [12]. The integrity of this type of preparation has been established by electron microscopy $[7,8,12,26]$. Following surgery, lasting approximately $20 \mathrm{~min}$, the pancreases were perfused for a $15 \mathrm{~min}$ stabilization period followed by a period of $3 \mathrm{~min}$ to obtain the basal immunoreactive insulin (IRI) levels. The release of insulin was then stimulated by perfusion with either $16.6 \mathrm{mmol} / 1$ glucose or $0.27 \mathrm{mmol} / 1$ tolbutamide in the basic buffer. In selected groups, some of the pancreases were perfused with basic buffer to obtain the basal insulin release corresponding to the period of stimulation of test pancreases of the same groups. During the one hour of perfusion, flow rates ranged from 5 to $10 \mathrm{ml} / \mathrm{min}$, and the perfusion pressure was $8.0 \mathrm{KPa}$. Insulin released into the perfusate was measured by radioimmunoassay.

\section{Experimental Design}

Table 1 summarises the protocol used in the glucose and tolbutamide experiments.

The glucose stimulation experiments were composed of 7 groups $(A-G)$. Groups A and B were controls. Groups $C$ to $G$ received one or more of the following drugs intraperitoneally: 5 -HTP ( $50 \mathrm{mg} / \mathrm{kg}$ body weight), nialamide ( $5 \mathrm{mg} / \mathrm{kg}$ body weight) and $\mathrm{RO} 4-4602(100 \mathrm{mg} / \mathrm{kg}$ body weight). Normal saline $(9 \mathrm{~g}$ $\mathrm{NaCl} / \mathrm{l}$ ) was used as a drug substitute. Pancreatic biopsies were obtained from 4 animals in each group immediately before and also after isolation of the pancreas for perfusion, to see if surgical manipulation altered the induced serotonin fluorescence in pancreatic islet cells. The pancreases of 12 animals from groups $\mathrm{A}$ and $B$, and 6 animals from groups $C$ to $G$ were perfused with $16.6 \mathrm{mmol} / 1$ glucose (Table 2 ). In addition 3 animals from groups $B$ and $E$ were perfused with basic buffer to provide the basal levels of IRI release for control and for animals with elevated pancreatic islet cell serotonin. In all instances pancreatic biopsies were obtained at the end of perfusion for histochemical evaluation of change in the intracellular serotonin content.

The tolbutamide stimulation experiments were composed of 2 groups ( $\mathrm{H}$ and $\mathrm{I})$ as shown in Table 1 . The pancreases of 5 saline control animals (Group $\mathrm{H}$ ) and 5 animals treated with nialamide and 5-HTP (Group 1) were challenged with $0.27 \mathrm{mmol} / 1 \mathrm{tol}-$ butamide (Table 2). Pancreatic biopsies for histochemical evaluation were taken following perfusion.

\section{Data Calculation}

The total insulin output is expressed as the integrated area under the insulin curve, which was 4 to 8 minutes $\left(\Sigma_{4}^{8}\right)$ for the first phase and 9 to 23 minutes $\left(\Sigma_{9}^{23}\right)$ for the second phase. Student's $t$ test was used to determine statistical significance for all comparisons between means. Differences were considered to be significant if $\mathrm{p}<0.05$. Results are presented as mean \pm SEM.

\section{Results}

The surgical procedure used to isolate the pancreas did not cause a detectable change of intesity of 5-HT formaldehyde-induced fluorescence (Fig. 1 and 2) nor the blocking effect of RO 4-4602 (Fig. 3). Fur- 
Table 2. Effect of elevated intracellular B cell serotonin on the biphasic glucose- and tolbutamide-mediated insulin release. The total insulin released (mean \pm SEM) and its distribution in Phase I and Phase II, in terms of amount $(\mu \mathrm{U})$ and percentage, are presented for each group

\begin{tabular}{|c|c|c|c|c|c|c|c|c|c|}
\hline \multirow[t]{2}{*}{ Stimulus } & \multirow{2}{*}{\multicolumn{2}{|c|}{ Group (n) Treatment }} & \multirow[t]{2}{*}{ Total Insulin ad } & \multicolumn{3}{|l|}{ Phase $\mathrm{I}^{\mathrm{b}}$} & \multicolumn{3}{|l|}{ Phase II $^{\mathrm{c}}$} \\
\hline & & & & $\overline{\text { Insulin }(\mu U)}$ & $\mathrm{p}$ & $\%$ of Total & Insulin $(\mu \mathrm{U})$ & $\mathrm{p}$ & $\%$ of Total \\
\hline \multirow{10}{*}{ Glucose } & A (12) & Untreated & $9577 \pm 1033$ & $1652 \pm 159$ & NS & 17.2 & $7925 \pm 896$ & NS & 82.8 \\
\hline & $B(12)$ & + Saline ${ }^{\mathrm{d}}$ & $11495 \pm 685$ & $2024 \pm 149$ & - & 17.6 & $9471 \pm 561$ & - & 82.4 \\
\hline & C (6) & Nialamide & & & & & & & \\
\hline & & + Saline $^{d}$ & $11317 \pm 1212$ & $2262 \pm 197$ & NS & 20.0 & $9054 \pm 1025$ & NS & 80.0 \\
\hline & $\mathrm{D}(6)$ & $\begin{array}{l}\text { Saline } \\
+5 \text {-HTPd }\end{array}$ & $11180 \pm 1505$ & $2149 \pm 264$ & NS & 19.2 & $9031 \pm 1283$ & NS & 80.8 \\
\hline & & & & & & & & & \\
\hline & & $\begin{array}{l}\text { Nialamide } \\
+5 \text {-HTPd }\end{array}$ & $10098 \pm 915$ & $1843 \pm 195$ & NS & 18.3 & $8255 \pm 739$ & NS & 81.7 \\
\hline & $F(6)$ & RO 4-4602 & & & & & & & \\
\hline & & $\begin{array}{l}+ \text { Nialamide } \\
+5 \text {-HTPd }\end{array}$ & $6662 \pm 422$ & $1123 \pm 86$ & $<0.001$ & 16.9 & $5538 \pm 459$ & $<0.001$ & 83.1 \\
\hline & $\mathrm{G}(6)$ & $\begin{array}{l}\text { RO 4-4602 } \\
+ \text { Saline } \\
+ \text { Saline }\end{array}$ & $7484 \pm 1142$ & $1334 \pm 207$ & $<0.02$ & 17.8 & $6149 \pm 963$ & $<0.01$ & 82.2 \\
\hline \multirow[t]{3}{*}{ Tolbutamide } & H (5) & Saline & & & & & & & \\
\hline & & + Saline $^{d}$ & $3125 \pm 161$ & $941 \pm 110$ & - & 30.1 & $2184 \pm 121$ & - & 69.9 \\
\hline & I (5) & $\begin{array}{l}\text { Nialamide } \\
+5 \text {-HTpd }\end{array}$ & $2462 \pm 638$ & $681 \pm 138$ & NS & 277 & $1781+519$ & NS & 723 \\
\hline
\end{tabular}

a Values for total insulin are expressed as integrated areas under the insulin curve [4-23 min]

b Phase I was determined by the first peak response which was over 5 min after initiation of the stimulus. Values are expressed as integrated areas under the insulin curve [4-8 min]

c Phase II was arbitrarily determined beginning by $\min 6$ after initiation of the stimulus and lasting until the end of the glucose infusion.

Values are expressed as integrated area under the insulin curve [9-23 min]

d Given after an interval of $1 \mathrm{~h}$

NS Not significantly different relative to saline controls (values were considered significant when $\mathrm{p}<0.05$ )

thermore, the apparent intensity of 5-HT formaldehyde-induced fluorescence (Fig. 4) and the basal IRI release (Fig. 5) were not modified by perfusion with the basic buffer.

\section{Effect of Intracellular B Cell Serotonin on Glucose-mediated Insulin Release}

Controls (Groups $A$ and B). Glucose elicited a typical biphasic IRI secretion pattern in untreated (Group A) as well as in saline-injected (Group B) controls (Table 2, Fig. 5). Since no significant difference was found between groups A and B, all treated groups were compared to saline controls for analysis of drug effects.

Test Animals (Groups $C-G$ ). The biphasic pattern of glucose-mediated insulin release was observed in all instances. In Group C, treated with nialamide alone, the first peak was slightly higher $(1 / 3)$ and shorter lived ( $3 \mathrm{~min}$ ) than that obtained in Group B. Nevertheless, the total insulin release in each phase did not differ significantly from the corresponding phase in the saline controls (Table 2 and Fig. 5).

Despite the elevated intracellular B cell serotonin in Group D (5-HTP alone) and Group E (nialamide and 5-HTP), neither the pattern nor the total amount of insulin released were found to be statistically different from that of the saline controls (Table 2 and Fig. 5).

The biphasic pattern was repeated in Group $\mathrm{F}$ (RO 4-4602, nialamide and 5-HTP) and Group G (RO 4-4602 alone). However, total insulin release was significantly reduced. In Group F, Phase I was reduced by $44.6 \%$ and Phase II by $41.6 \%$. In group G Phase I was reduced by $34.1 \%$ and Phase II by $35.2 \%$. Thus, the proportion of insulin release in Phase I and II was essentially the same as in Group B (Table 2 and Fig. 5).

After glucose stimulation, islet cells of pancreases from Groups A, B, C, F and G were not fluorescent, whereas, those from Groups D (Fig. 7) and E (Fig. 6) exhibited a yellow fluorescence that was most intense in Group E. 

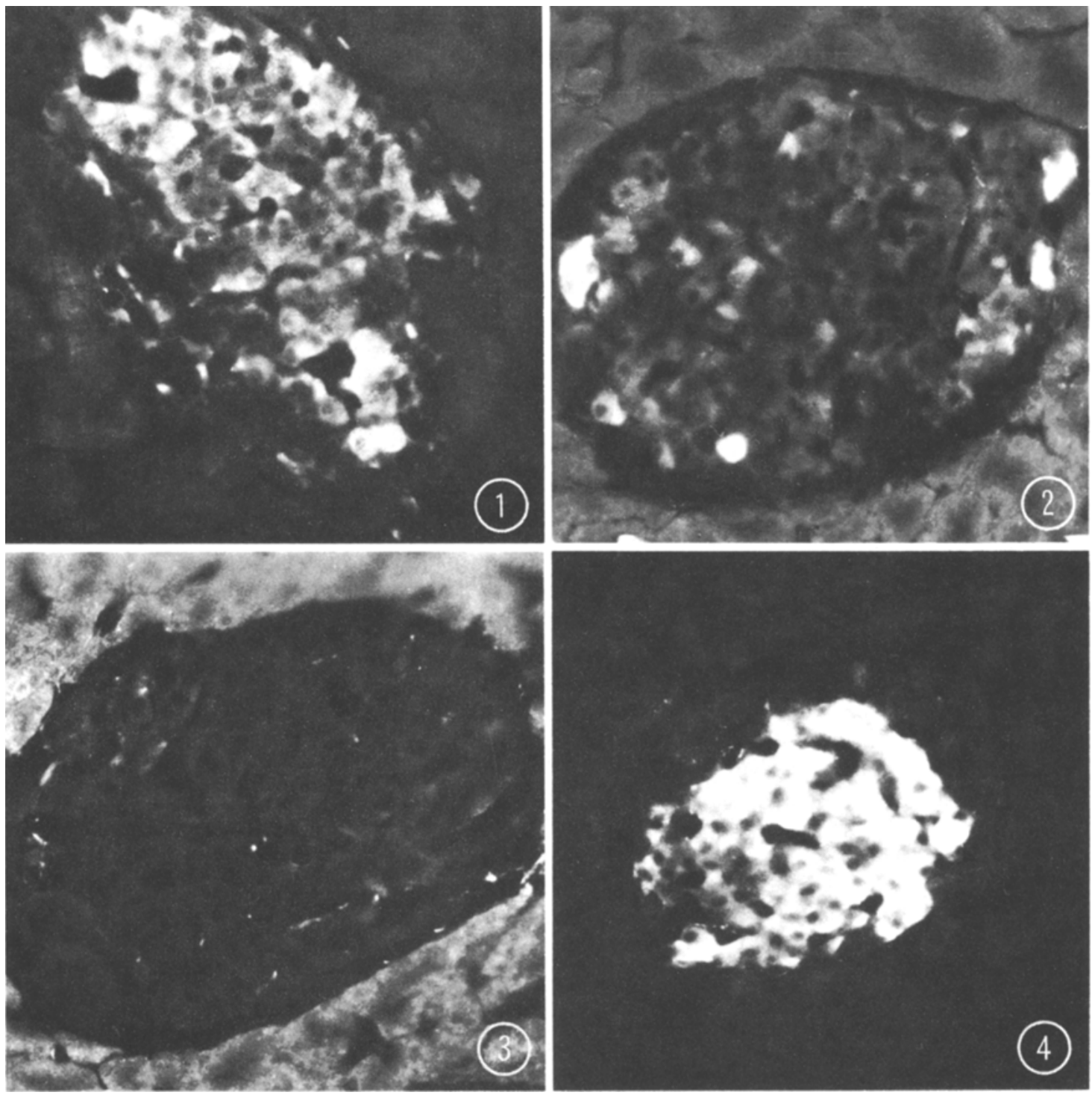

Fig. 1. Intense cytoplasmic fluorescence is desplayed by islet cells from a rat pretreated with nialamide ( $5 \mathrm{mg} / \mathrm{kg}$ body weight) and $5-\mathrm{HTP}$ $(50 \mathrm{mg} / \mathrm{kg}$ body weight). Tissue was removed after isolation of pancreas and before perfusion. $360 \times$

Fig. 2. Moderate cytoplasmic fluorescence is displayed by islet cells from a rat pretreated with $5-\mathrm{HTP}$ ( $50 \mathrm{mg} / \mathrm{kg}$ body weight alone). Tissue removed after isolation of pancreas and before perfusion. $360 \times$

Fig. 3. Non-fluorescent islet cells from a rat pretreated with RO $4-4602(100 \mathrm{mg} / \mathrm{kg}$ body weight), nialamide ( $5 \mathrm{mg} / \mathrm{kg} \mathrm{body} \mathrm{weight)} \mathrm{and}$ 5 -HTP $(50 \mathrm{mg} / \mathrm{kg}$ body weight). Tissue was removed after isolation of pancreas and before perfusion. $360 \times$

Fig. 4. Intense cytoplasmic fluorescence is displayed by pancreatic islet cells from a rat pretreated with nialamide (5 mg/kg body weight) and $5-\mathrm{HTP}$ ( $50 \mathrm{mg} / \mathrm{kg}$ body weight). Pancreas was removed at the end of perfusion with $4.4 \mathrm{mmol} / 1$ glucose. $360 \times$

\section{Effect of Intracellular B Cell Serotonin on Tolbutamide-Stimulated Insulin Release}

Saline Control (Group H). Stimulation with tolbutamide elicited the characteristic single peak in Phase I followed by a sustained secretion rate above the basal level lasting until the termination of the stimulus in Phase II (Fig. 5).

Nialamide and 5-HTP (Group I). Despite the elevated intracellular B cell serotonin in Group I, the pattern and the total amount of insulin released in 

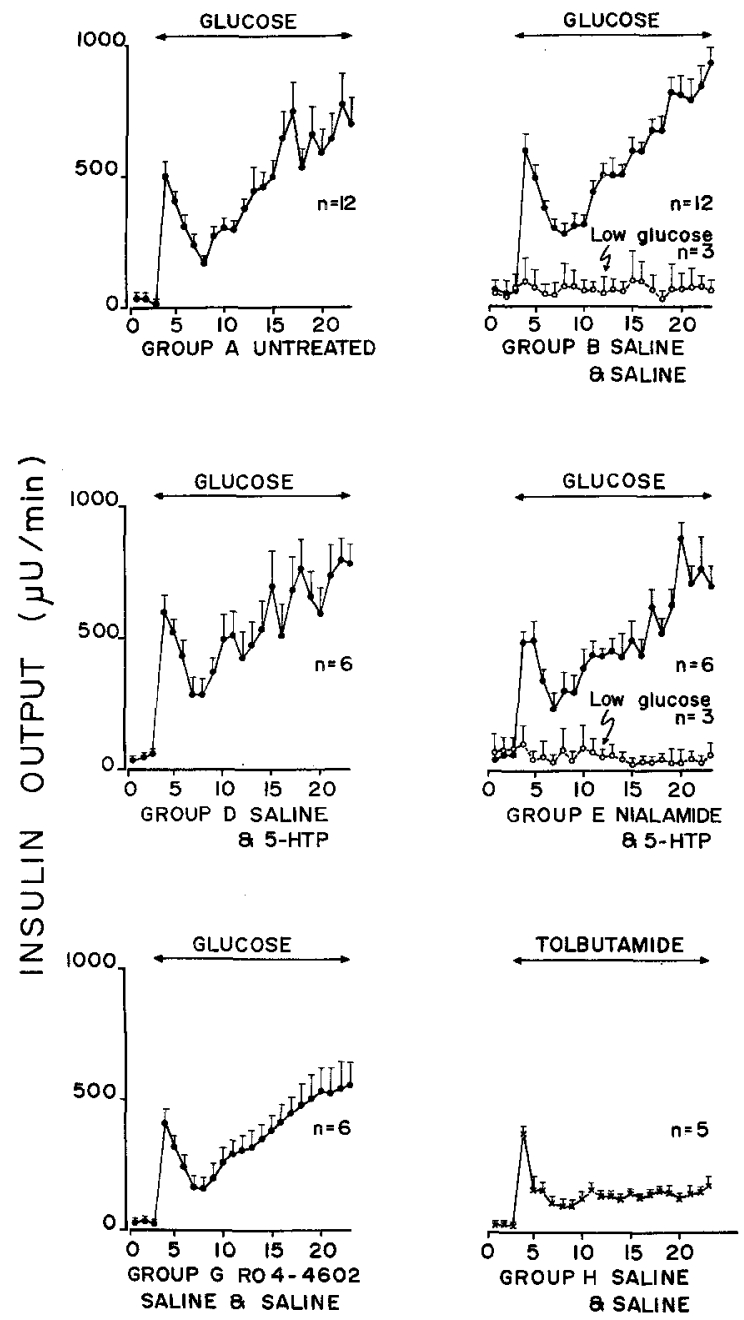

TIME (min)


Fig. 5. Dynamics of insulin release in each test group. The first three points in each curve depict the basal IRI levels obtained during perfusion with $4.4 \mathrm{mmol} / \mathrm{l}$ glucose. The stimulation period is designated by a horizontal line above each curve. The superscript identifies the stimulus, either $16.6 \mathrm{mmol} / \mathrm{l}$ glucose $(\bullet-)$ ) or $0.27 \mathrm{mmol} / \mathrm{l}$ tolbutamide ( $\mathrm{x}-\mathrm{x}$ ). In Groups $\mathrm{B}$ and $\mathrm{E}$ the basal insulin levels obtained by perfusion with low glucose $(\bullet \bullet)$ are indicated by an arrow response to tolbutamide was similar to that of Group $\mathrm{H}$ (Table 2 and Fig. 5).

The persistence of high levels of intracellular B cell serotonin during tolbutamide stimulation was confirmed by histochemical examination of islet cells which revealed an intense yellow fluorescence in Group I (Fig. 8). This reaction was absent in islet cells of saline controls.

\section{Discussion}

In the present work, it has been demonstrated that elevated intracellular B cell serotonin did not affect the pattern or amount of insulin released from the rat pancreas challenged with glucose or tolbutamide. These observations are in agreement with previous in vivo studies of glucose-mediated insulin release in mice [28] and humans [34] both pretreated with 5 -HTP.
Disparate to these findings is the inhibitory effect of elevated intracellular B cell serotonin on the release of insulin observed during incubation of tissue obtained from animals treated with the 5-HT precursor 5-HTP $[18,27,36,37]$. Whether this discrepancy is due to differences in experimental technique (i. e. incubation vs. perfusion), to species differences or other as yet unknown reasons remains to be determined.

It is worth noting that previous studies in our laboratory $[9,10,13]$ have shown that serotonin inhibited insulin response to a glucose challenge when it was incorporated into the perfusion fluid of a similar preparation to that used in the present studies. From this and the present study, it is concluded that under our experimental conditions, elevated intracellular B cell serotonin does not have an effect on insulin release, whereas extracellular serotonin inhibits this B cell function. It is not clear where this inhibition is effected. Since some evidence $[6,18]$ indicates 

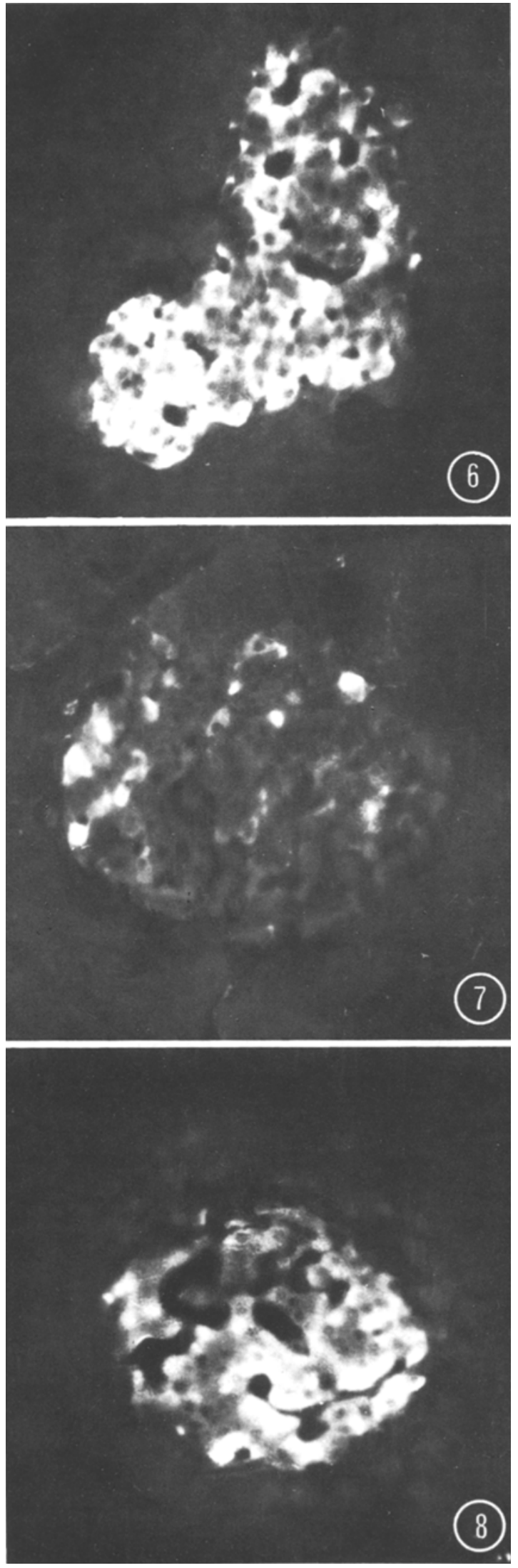

that serotonin penetrates cell membranes very poorly it is possible that extracellular serotonin acts on the cell membrane. However, these findings do not totally preclude penetration of some serotonin into B cells.

In view of the inhibitory action of extracellular serotonin on insulin release observed in our preparation, the question arises as to whether intracellular serotonin leakage from B cells, either physiologically [23] or through cell necrosis $[2,3]$, may result in sufficiently high local concentration of this amine to affect insulin release in vitro. This consideration appears relevant in the interpretation of data obtained using incubation of tissues from animals pretreated with 5-HTP $[18,27,36,37]$.

Species differences may also account for the disparity between our results and the inhibitory effect of elevated intracellular B cell serotonin observed in vitro by others $[18,27,37]$. In guinea pigs the $B$ cell contains high levels of intracellular serotonin which does not appear to compromise cellular function $[6$, 24]. However, if intracellular $B$ cell serotonin, which is not demonstrable in mice and rabbits, is elevated by the administration of 5-HTP, insulin release is abolished in mice [27] but only partially inhibited in rabbits $[18,36,37]$.

In studies in which the sulphonamide glibenclamide, or isoproterenol were used as the insulinogenic stimulus, pretreatment of mice with 5-HTP inhibited insulin release but did not affect the insulin response to a glucose callenge [28]. In our experiments the insulin release elicited by the sulphonamide tolbutamide was not inhibited after pretreatment with 5-HTP. The different insulin response to tolbutamide as compared to that of glibenclamide, in the presence of elevated intracellular B cell serotonin, may be the result of differences in the mechanisms of action of these two sulphonamides [21] or in experimental models.

The results of the perfusion experiments obtained when RO 4-4602 was administered to verify that the

Fig. 6. Intense cytoplasmic fluorescence is displayed by islet cells from a rat pretreated with nialamide $(5 \mathrm{mg} / \mathrm{kg}$ body weight) and $5-\mathrm{HTP}(50 \mathrm{mg} / \mathrm{kg}$ body weight). Pancreas was removed at the end of perfusion with $16.6 \mathrm{mmol} / \mathrm{l}$ glucose. $325 \times$

Fig. 7. Moderate cytoplasmic fluorescence is displayed by islet cells from a rat pretreated with $5-\mathrm{HTP}$ alone $(50 \mathrm{mg} / \mathrm{kg}$ body weight). Pancreas was removed at the end of perfusion with $16.6 \mathrm{mmol} / \mathrm{l}$ glucose. $325 x$

Fig. 8. Intense cytoplasmic fluorescence is displayed by islet cells from a rat pretreated with nialamide $(5 \mathrm{mg} / \mathrm{kg}$ body weight) and 5-HTP ( $50 \mathrm{mg} / \mathrm{kg}$ body weight). Pancreas was removed at the end of perfusion with $0.27 \mathrm{mmol} / 1$ tolbutamide. $325 \times$ 
formaldehyde induced fluorescence was due to serotonin, were unexpected. The administration of RO 4-4602, which blocks the synthesis of 5-HT from 5-HTP, resulted in an inhibition of glucose mediated insulin release whether or not pretreatment with 5-HTP was carried out. The implication of this finding is not clear. A possible explanation is that RO 4-4602 exerts an independent pharmacological effect responsible for the observed inhibition of insulin release.

The above findings with our experimental model precludes the generalisation of the hypothesis that intracellular B cell serotonin acts as inhibitor of insulin release $[18,25]$. Clearly, further work on the role of intracellular B cell serotonin is required. Such studies must include the rat together with other species so that the question of species differences in sensitivity to increased levels of intracellular B cell serotonin may be answered.

Acknowledgements. It is a pleasure to acknowledge the excellent technical assistance of Mr. B. Gubbins and Miss M. Chiong, and the expert secretarial assistance of Mrs. B. Fluhrer and Mrs. Audrey Davison.

\section{References}

1. Baldrigde, J. A., Quickel, K. E., Jr., Feldman, J. M., Lebovitz, H. E.: Potentiation of tolbutamide-mediated insulin release in adult onset diabetics by methysergide maleate. Diabetes $\mathbf{2 3}$, 21-24 (1974)

2. Bencosme, S. A., Wilson, M. B., Aleyassine, H., de Bold, A. J., de Bold, M. L.: Rabbit pancreatic B cell. Morphological and functional studies during embryonal and post-natal development. Diabetologia 6, 399-411 (1970)

3. Bencosme, S. A., Tsutsumi, V., Martin, J.M., Åkerblom, H. K.: Ultrastructural changes in B cells of pancreatic islets from rats with elevated levels of circulating growth hormone secreted by MtT-W 15 tumor. Diabetes 20, 15-26 (1971)

4. Bivens, C. H., Lebovitz, H. E., Skyler, J. S., Feldman, J. M.: Enhancement of insulin secretion in acromegaly by serotonin antagonists (Abstract). Diabetes 21 (Suppl 1), 352 (1972)

5. Björklund, A., Falck, B., Owman, Ch.: Fluorescence microscopic and microspectrofluorometric technique for the cellular localization and characterization of biogenic amines. In: $\mathrm{S}$. A. Berson (Ed.): Methods in investigative and diagnostic endocrinology; J. E. Rall, I. J. Kopin (Eds.): The thyroid and biogenic amines, p. 318-335. Amsterdam: North-Holland Publishing Company (Publishers); New York: American Elsevier Publishing Company, Inc. (Distributors) 1972

6. Cegrell, L.: The occurrence of biogenic monoamines in the mammalian endocrine pancreas. Acta Physiol. Scand. [Suppl.] 314, 1-60 (1968)

7. Curry, D. L., Bennet, L. L., Grodsky, G. M.: Dynamics of insulin secretion by the perfused rat pancreas. Endocrinology 83, 572-584 (1968)

8. de Bold, M. L.: Establishment of an in situ perfused pancreas preparation to study the biphasic release of insulin. In: regulatory role of serotonin during the first phase of insulin release. A morphological and functional study, p. 92-109. Ph. D. Thesis, Department of Pathology, Queen's University, Kingston, Ontario, Canada 1974
9. de Bold, M. L.: The effects of serotonin on B cell structure and function during the glucose-mediated first phase of insulin release. In: Regulatory role of serotonin during the first phase of insulin release. A morphological and functional study, p. 175-196. Ph. D. Thesis, Department of Pathology, Queen's University, Kingston, Ontario, Canada 1974

10. de Bold, M. L., Bencosme, S. A.: Inhibition of the first phase of glucose mediated insulin release by serotonin in an in situ perfused pancreas preparation (Abstract). Fed. Proc. 42, 253 (1975)

11. de Bold, M. L., Bencosme, S. A.: Morphological changes occurring in rat $B$ cells following stimulation or inhibition of the first phase of insulin release (Abstract). Anat. Rec. 181, 342 (1975)

12. de Bold, M. L., Bencosme, S. A., Penhos, J. C.: The ultrastructure of B-cell during the biphasic release of insulin after using dextran as albumin substitute (Abstract). Lab. Invest. 32, 422 (1975)

13. de Bold, M. L., Bencosme, S. A.: Effects of serotonin and its antagonists on the first phase of insulin release in normal and hypersomatotropic rats. Horm. Metab. Res. (Accepted for publication) (1978)

14. Feldman J. M., Lebovitz, H. E.: Specificity of serotonin inhibition of insulin release from golden hamster pancreas. Diabetes 19, 475-479 (1970)

15. Feldman, J.M., Lebovitz, H. E.: Mechanism of epinephrine and serotonin inhibition of insulin release in the golden hamster in vitro. Diabetes 19, 480-486 (1970)

16. Feldman, J.M., Lebovitz, H. E.: Serotonin inhibition of in vitro insulin release from golden hamster pancreas. Endocrinology 86, 66-70 (1970)

17. Feldman, J. M., Lebovitz, H. E.: Antagonism of catecholamine inhibition of insulin secretion by methysergide. Experientia 28, 433-434 (1972)

18. Feldman, J. M., Lebovitz, H. E.: A serotoninergic mechanism for the control of insulin secretion. Trans. Assoc. Am. Physicians 85, 279-294 (1972)

19. Feldman, J.M., Quickel, K. E., Jr., Lebovitz, H. E.: Potentiation of insulin secretion in vitro by serotonin antagonists. Diabetes 21, 779-788 (1972)

20. Feldman, J. M., Bivens, C. H., Skyler, J. S., Lebovitz, H. E.; Effect of cyproheptadiene administration on insulin secretion in acromegalic, diabetic and normal subjects. Horm. Metab. Res. 7, 279-283 (1975)

21. Fubganger, R. D., Goberna, R., Hinz, M., Jaros, P., Karsten, C., Pfeiffer, E. F., Raptis, S.: Comparative studies on the dynamics of insulin secretion following HB 419 and tolbutamide of the perfused isolated rat pancreas and the perifused isolated pieces and islets of rat pancreas. Horm. Metab. Res. (Suppl), 34-40 (1969)

22. Gagliardino, J. J., Nierle, C., Pfeiffer, E. F.: The effect of serotonin on in vitro insulin secretion and biosynthesis in mice. Diabetologia 10, 411-414 (1974)

23. Gylfe, E.: Concomitant release of serotonin and insulin from perifused pancreatic islets (Abstract). Diabetologia 13, 398 (1977)

24. Jaim-Etcheverry, G., Zieher, L. M.: Electron microscopic cytochemistry of 5-hydroxytryptamine (5-HT) in the beta cells of guinea pig endocrine pancreas. Endocrinology 83, 917-923 (1968)

25. Lebovitz, H. E., Feldman, J. M.: Pancreatic biogenic amines and insulin secretion in health and disease. Fed. Proc. 32, 1797-1802 (1973)

26. Lee, J. C., Grodsky, G. M., Bennett, L. L., Smith-Kyle, D. F., Craw, L.: Ultrastructure of $B$ cells during the dynamic response to glucose and tolbutamide in vitro. Diabetologia 6, 542-549 (1970) 
27. Lernmark, A.: The significance of 5-hydroxytryptamine for insulin secretion in the mouse. Horm. Metab. Res. 3, 305-309 (1971)

28. Lundquist, I., Ekholm, R., Ericson, L. E.: Monoamines in the pancreatic islets of the mouse. 5-hydroxytryptamine as an intracellular modifier of insulin secretion and the hypoglycaemic action of monoamine oxidase inhibitors. Diabetologia 7, 414-422 (1971)

29. Penhos, J.C., Wu, C. H., Basabe, J. C., Lopez, N., Wolff, F. W.: A rat pancreas-small gut preparation for the study of intestinal factor(s) and insulin release. Diabetes 18, 733-738 (1969)

30. Pontiroli, A. E., Viberti, G. C., Tognetti, A., Pozza, G.: Effect of metergoline, a powerful and long-acting antiserotoninergic agent, on insulin secretion in normal subjects and in patients with chemical diabetes. Diabetologia 11, 165-167 (1975)

31. Pulido, O., de Bold, A., de Bold, M. L., Bencosme, S. A.: Demonstration of a tryptaminergic mechanism in the rat $B$ cell. Experientia 33, 268-269 (1977)

32. Quickel, K. E., Jr., Feldman, J. M., Lebovitz, H. E.: Inhibition of insulin secretion by serotonin and dopamine. Species variation. Endocrinology 89, 1295-1302 (1971)

33. Quickel, K. E., Jr., Feldman, J. M., Lebovitz, H. E.: Enhancement of insulin secretion in adult onset diabetics by methysergide maleate: Evidence for an endogenous biogenic monoamine mechanism as a factor in the impaired insulin secretion in diabetes mellitus. J. Clin. Endocrinol. Metab. 33, 877-881 (1971)
34. Seino, Y., Ikeda, M., Kuzuya, H., Sakurai, H., Imura, H.: Effect of 5-hydroxytryptophan (5-HTP), L-Dopa and Bethanidine on plasma insulin response to intravenous glucose loading in normal subjects. Horm. Metab. Res. 7, 92-93 (1975)

35. Smith, P. H., Porte, D., Jr.: Neuropharmacology of the pancreatic islets. Annu. Rev. Pharmacol. Toxicol. 16, 269-285 (1976)

36. Tjalve, H.: Catechol- and indolamines in some endocrine cell systems. An autoradiographical, histochemical and radioimmunological study. Acta Physiol. Scand. [Suppl 360] 81, 1-122 (1971)

37. Wilson, J. P., Downs, R. W., Jr., Feldman, J. M., Lebovitz, H. E.: Beta cell monoamines: Further evidence for their role in modulating insulin secretion. Am. J. Physiol. 227, 305-312 (1974)

Received: November 11, 1977,

and in revised form: April 21, 1978

Dr. A. J. de Bold

Department of Pathology

Hotel Dieu Hospital

Kingston, Ontario

Canada K7L 3H6 